\title{
ポリロタキサンの分子構造・ダイナミクスと環動ゲルのカ学物性
}

\author{
眞弓 皓一, 伊藤 耕三 \\ (東京大学大学院 新領域創成科学研究科)
}

\section{Structure and Dynamics of Polyrotaxane and Mechanical Properties of Slide-ring Gels}

Koichi Mayumi and Kohzo Ito

Graduate School of Frontier Sciences, University of Tokyo

\section{0

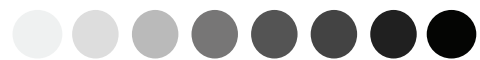

\begin{abstract}
Polyrotaxane (PR) is a typical supramolecule, in which cyclic molecules are threaded onto a linear polymer chain. The cyclic molecules in PR can slide and rotate on the polymer chain. PR has been applied to a novel kind of polymer network, called "slide-ring (SR) gel", which is prepared by cross-linking cyclic molecules belonging to different PRs. The cross-linking point of SR gels can slide along the polymer chains, and this unique structure causes the high extensibility of SR gels. We have investigated the structure and dynamics of PR at molecular level by contrast variation small-angle neutron scattering and neutron spin echo. The contrast variation methods allow us to elucidate the structure and dynamics of rings and polymers separately. Furthermore, we studied the macroscopic mechanical properties of SR gels and proposed a novel molecular theory for SR gels, which considered the alignment entropy of cyclic molecules on polymer networks.
\end{abstract}

Keywords: gels, small-angle neutron scattering, neutron spin echo, contrast variation

\section{1.はじめに}

従来の合成高分子は低分子量モノマーを共有結 合によって重合したものがほとんどであったが， 近年超分子化学の技法を応用することで，非共有 結合を利用した高分子の分子設計が行われるよう になっている[1]. 超分子化学とは, 水素結合, 疎 水性相互作用， van der Waals 力などの共有結合以 外の結合を利用することで分子複合体を構築する 有機化学の一分野である [2]. 我々は非共有結合 によって形成された超分子ポリマーのうち，幾何 学的な絡み合いによって集合した分子複合体であ るトポロジカル超分子 (mechanically interlocked molecules）に着目している [3,4]. トポロジカル超 分子の代表例としては, 環状分子が相互貫入した カテナンや，軸分子が環状分子を貫通し，更に環 状分子が抜けないように軸分子の末端が封鎖され たロタキサンなどがある。ロタキサンのうち，環 状分子を複数個含むものをポリロタキサンと呼ぶ

(Fig.1 左). トポロジカル超分子の特長は, 各分 子が幾何学的な拘束によって束縛されながらも， 相対的な運動自由度を残している点にある。例え ば，ロタキサンの場合, 内部の環状分子は軸分子 上を自由に回転およびスライドすることができる. この分子内運動自由度を利用することで，従来の

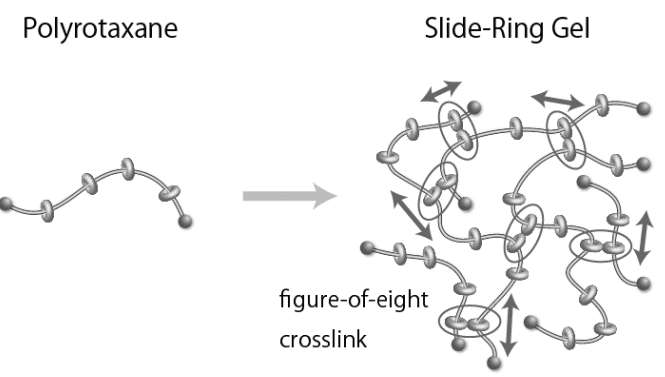

Fig.1 Schematic view of polyrotaxane and slide-ring gels.

高分子と異なる動的物性を持った新規機能性材料 が生み出されている[5,6,7].

環状分子の軸分子上における回転・スライドの 運動自由度を利用したロタキサンの応用例として は, $\mathrm{pH}$ などの外場によって環状分子の軸分子上に おける位置を制御する分子スイッチ[8]や，環状分 子に薬物を担持させたドラッグデリバリーシステ ム[9]などが提案されているが，実用には至ってい ない.このような分子レベルのナノ材料に加えて, 巨視的な新規材料として，幾何学的な分子結合に よって高分子鎖を架橋した高分子架橋体が開発さ れている[6,7]. 奥村らは，ポリロタキサンの環状 分子間を化学架橋することで，ポリロタキサンが 
8 の字の架橋点によって連結された高分子ネット ワークを作製し，環動ゲル（Slide-Ring Gel）と名 付けた（Fig.1 右） [10]. 高分子鎖が共有結合に よって直接架橋された従来の化学ゲルでは，架橋 点間分子量に大きな分子量分散があるため，ゲル を変形させると短い鎖に応力が集中し，小さな変 形で破壊に至ってしまう（Fig.2 (a)）。一方，環動 ゲルにおいては，8 の字架橋点を通して短い分子 鎖に他の部分から鎖が供給され，ゲル内部の応力 集中が緩和される（Fig.2 (b)）。したがって，環動 ゲルは従来の化学ゲルに比べて高分子鎖の破断が 起こりにくいことが期待される. (a) chemical gel

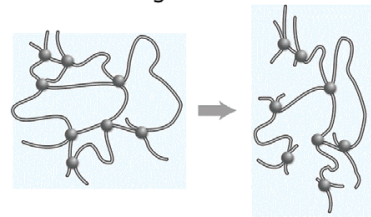

(b) slide-ring gel

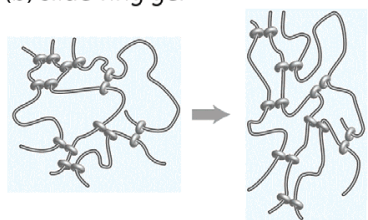

Fig.2 Schematic comparison between chemical and slide-ring gel.

ポリロタキサンのナノ材料への応用が進展する 一方で，ポリロタキサンの分子レベルにおける静 的構造および分子ダイナミクスに関する基礎研究 は，機能性材料の分子設計に不可欠であるにも関 わらず，十分に行われてこなかった。最大の問題 は，ポリロタキサンが環状分子と軸高分子からな る多成分系であり，その分子レベルにおける振る 舞いを明らかにするためには，各成分の情報を分 離する必要があることである。本稿では，コント ラスト変調中性子散乱法を用いることで，ポリロ タキサン中の環状分子と軸高分子の微視的構造お よび分子ダイナミクスをそれぞれ分離して観察し た結果について報告する。ささら環状分子のスラ イド運動と環動ゲルの力学物性とをつなぐ分子論 についてもあわせて紹介寸る。

2. コントラスト変調 SANS を用いたポリロタキ サンの分子構造解析

本節では，溶液中におけるポリロタキサンの分 子構造をコントラスト変調小角中性子散乱法

（CV-SANS）によって調べた結果について述べる [11,12]. ポリロタキサン溶液は，環状分子，軸高 分子, 溶媒の 3 成分系であり, その散乱関数は 3 つの部分散乱関数の足し合わせとして表される (Fig.3) :

$I(Q)=\Delta \rho_{\mathrm{C}}^{2} S_{\mathrm{CC}}(Q)+\Delta \rho_{\mathrm{P}}^{2} S_{\mathrm{PP}}(Q)+2 \Delta \rho_{\mathrm{C}} \Delta \rho_{\mathrm{P}} S_{\mathrm{CP}}(Q)$

$S_{\mathrm{CC}}(Q)$ は環状分子の自己相関, $S_{\mathrm{PP}}(Q)$ は軸高分子の 自己相関, $S_{\mathrm{CP}}(Q)$ は軸分子 - 環状分子間の相互相 関を表す部分散乱関数である. $\Delta \rho_{\mathrm{i}}$ は成分 $\mathrm{i}$ と溶媒 との散乱長密度差であり, 各成分の散乱コントラ ストを表す (C：環状分子，P：高分子). ポリロ タキサンの分子構造を求めるためには，それぞれ の部分散乱関数を解析する必要がある. $S_{\mathrm{CC}}(Q)$ か
らは環状分子の軸高分子上における配列， $S_{\mathrm{PP}}(Q)$ からは軸分子の形態, $S_{\mathrm{CP}}(Q)$ からは環状分子と軸 高分子の空間相関が分かる. 部分散乱関数 $S_{\mathrm{ij}}(Q)$ は，重水素化によって散乱コントラスト $\Delta \rho_{\mathrm{i}}$ を 様々に変調させた試料の散乱関数 $I(Q)$ を, 式(1)に 基づいて解析することで得られる.

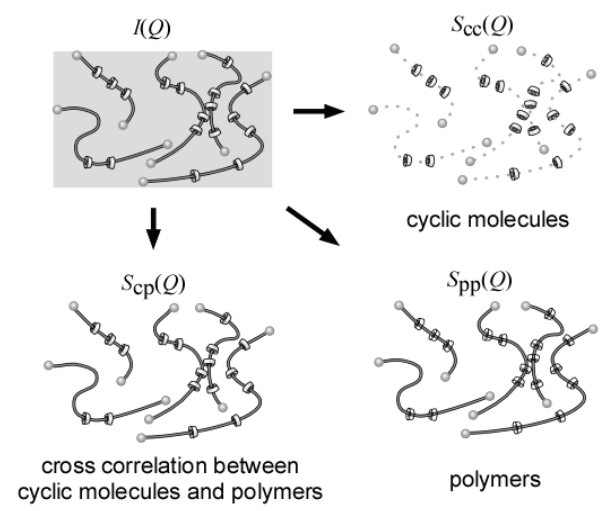

Fig.3 Schematic representations of polyrotaxane in solution showing the decomposition of scattering intensity $I(Q)$ into partial scattering functions.

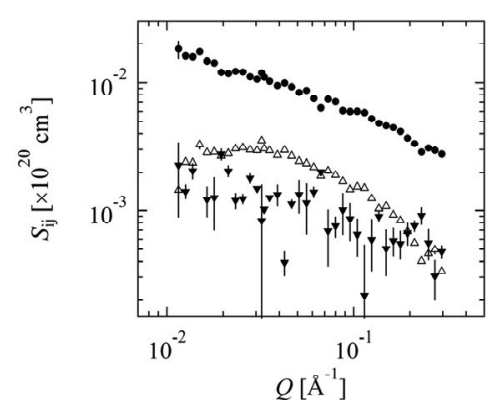

Fig.4 Partial scattering functions of CD-CD, $S_{\mathrm{CC}}(\bullet)$; PEG-PEG, $S_{\mathrm{PP}}(\boldsymbol{\nabla})$; and CD-PEG, $S_{\mathrm{CP}}(\Delta)$.

実験には，ポリエチレングリコール（PEG）を 軸高分子， $\alpha$-シクロデキストリン $(\mathrm{CD})$ を環状分 子とするポリロタキサンを用いた。コントラスト を変調するために, 通常の h 体のポリロタキサン (h-PR) に加えて, 重水素化 PEG を軸高分子とし たポリロタキサン（d-PR）を合わせて合成した. 溶媒はジメチルスルホキシド（h-DMSO） と重水 素化 DMSO（d-DMSO）の混合溶媒を用いた。 d-DMSO と h-DMSO の混合比率を h-PR, d-PR そ れぞれに対して 4 点変化させることで計 8 点のコ ントラストで SANS 実験を行った. Fig.4 にその散 乱関数を成分分解することによって得られた部分 散乱関数を示す。まず，相互相関を表す $S_{\mathrm{CP}}(Q)$ は 正の值となり，この正の相関はポリロタサン中の 環状分子と軸分子とが互いに幾何学的に絡み合っ ていることを意味している. ポリロタキサンの超 分子構造を裏付ける決定的な実験結果である。ま た, 軸分子の形状を表す $S_{\mathrm{PP}}(Q)$ と環状分子の構造 を表す $S_{\mathrm{CC}}(Q)$ がほぼ同様の $Q$ 依存性を示している ことから，ポリロタキサン中の環状分子は軸高分 子上にランダムに配列していることが分かった。 
また, $S_{\mathrm{PP}}(Q)$ を worm-like chain model の散乱関数を 用いて解析したところ, ポリロタキサンのセグメ

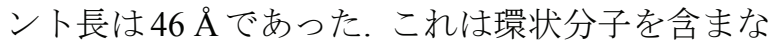
い軸分子単独の場合の約 2 倍の值であり，環状分 子の存在によって軸分子が剛直になることが定量 的に示された.

3. コントラスト変調 NSE を用いたポリロタキサ ンの分子ダイナミクスの観察

ポリロタキサンの最大の特徵は，環状分子が軸 高分子上に束縛されながらも，回転およびスライ ドという相対的な運動自由度を残している点にあ る。我々は，CD と PEGからなるポリロタキサン の溶液中における分子ダイナミクスを中性子スピ ンエコー法（NSE）によって調べた $[13,14]$. 中性 子スピンエコー法を用いた理由は以下の 2 つであ る.まず，中性子スピンエコー法は CD および高 分子セグメントの運動を直接観察するには最も適 した $\mathrm{nm}$ スケールの空間分解能を有している点が 挙げられる[15]. 2つ目の理由としては, 前節で用 いたコントラスト変調法を NSE に適用すること で，ポリロタキサンのような環状分子と線状高分 子からなる多成分系において, 各構成要素のダイ ナミクスを分離して調べることができることであ る.

\section{1 コントラスト変調 NSE の原理}

$\mathrm{CD}, \mathrm{PEG}$, 溶媒の 3 成分系であるポリロタキサ ン溶液の規格化された中間散乱関数は, 以下のよ うに記述される：

$$
\begin{aligned}
& \frac{I(Q, t)}{I(Q)}=\Delta \rho_{\mathrm{C}}{ }^{2} \frac{S_{\mathrm{CC}}(Q)}{I(Q)} \frac{S_{\mathrm{CC}}(Q, t)}{S_{\mathrm{CC}}(Q)} \\
& +\Delta \rho_{\mathrm{P}}{ }^{2} \frac{S_{\mathrm{PP}}(Q)}{I(Q)} \frac{S_{\mathrm{PP}}(Q, t)}{S_{\mathrm{PP}}(Q)}+2 \Delta \rho_{\mathrm{C}} \Delta \rho_{\mathrm{P}} \frac{S_{\mathrm{CP}}(Q)}{I(Q)} \frac{S_{\mathrm{CP}}(Q, t)}{S_{\mathrm{CP}}(Q)}
\end{aligned}
$$

ここで， $S_{\mathrm{CC}}(Q, t)$ および $S_{\mathrm{PP}}(Q, t)$ はそれぞれ $\mathrm{CD}$, PEG の自己拡散, $S_{\mathrm{CP}}(Q, t)$ は $\mathrm{CD}$ と $\mathrm{PEG}$ 間の相対 運動に対応する部分散乱関数である. $S_{\mathrm{ij}}(Q)$ は前節 で扱った静的な部分散乱関数である。式(2)より, 多成分系の $I(\mathrm{Q}, t) / I(Q)$ は, 各成分の自己相関ある いは成分間の相互相関に対応する $S_{\mathrm{ij}}(Q, t) / S_{\mathrm{ij}}(Q)$ の 足し合わせとなる. 足し合わせの重みは，各成分 の散乱コントラスト $\Delta \rho_{\mathrm{i}}, \Delta \rho_{\mathrm{j}}$ とそれらの静的な散 乱強度 $S_{\mathrm{ij}}(Q)$ によって定まる。 コントラスト変調 NSEによる運動モードの分離は以下の手順で行え ばよい. (1) まずコントラスト変調 SANS によっ て静的な部分散乱関数 $S_{\mathrm{ij}}(Q)$ を測定する. (2) 様々 なコントラストで NSE 測定を行い， $I(\mathrm{Q}, t) / I(Q)$ を実測する。(3) (1), (2)によって得られた $I(\mathrm{Q}$, $t) / I(Q)$ から，式(2)を用いて $S_{\mathrm{ij}}(Q, t) / S_{\mathrm{ij}}(Q)$ を算出す る.

\section{2 結果と考察}

我々は, PEG および CD を重水素化することに よって散乱コントラストの異なる 3 種類のポリロ タキサン溶液を調整した。まず, PEG はh-PEGに
加えて, 溶媒である d-DMSO と散乱長密度が完全 に一致する（コントラストが消える）ように，h 体モノマーと d 体モノマーを 3:7 の比率で重合し た部分重水素化 PEG (dh-PEG) を準備した. また, $\mathrm{CD}$ は水酸基に $\mathrm{h}$ 体および $\mathrm{d}$ 体のヒドロキシプロ ピル基を導入することで散乱コントラストを変化 させた. 合成したポリロタキサンは 3 種類であり, $\mathrm{PEG} \cdot \mathrm{CD}$ ともに $\mathrm{h}$ 体である h-PEG/h-CD, CD か らの散乱が支配的である dh-PEG/h-CD，逆に PEG からの散乱が強い h-PEG/d-CD である。溶媒には d-DMSO を用い，ポリロタキサン溶液の高分子濃 度は 5\%とした。

Fig.5 5 種類のポリロタキサン溶液の中間散乱 関数を示す $\left(Q=0.08 \AA^{-1}\right) . \quad P E G$ と CD が互いに スライド運動をするなど独立した運動モードを有 している場合,散乱コントラストを変えることに よって中間散乱関数は変化することが予想された が，実際の実験結果としては，3 種類のポリロタ キサン溶液の中間散乱関数はほぼ同じであった。

つまり, PEG セグメントの運動を表わす $S_{\mathrm{PP}}(Q, t)$ と $\mathrm{CD}$ の運動を表わす $S_{\mathrm{CC}}(Q, t)$ は観察した時間領

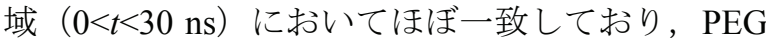
と CD の相対運動であるスライド運動はPEGのセ グメント運動よりも十分遅いということである.

NSE の時間領域では，CD は PEG に引きつられ て運動しており，両者の運動を区別する必要はな い. 以下，ポリロタキサンを一つの高分子鎖とし て粗視化して考え，h-PEG/h-CD の中間散乱関数 を詳しく解析する。ポリロタキサン溶液 (h-PEG/h-CD) の中間散乱関数の短時間部分 $(0<t<10 \mathrm{~ns})$ を単一指数関数 $\exp (-\Gamma \mathrm{t})$ によってフ イッティングした. Fig.6に $\Gamma / Q^{2}$ の $Q$ 依存性を示 す. 比較のために同じ高分子濃度（5\%）の PEG 溶液の結果も合わせて示している. PEG 溶液とポ リロタキサン溶液を比較すると, 初期緩和速度 はポリロタキサン溶液の方が小さい值となってい ることが分かる。つまり，PEGの局所ダイナミク スは CD に包接されることによって抑制される. PEG 溶液，ポリロタキサン溶液ともに， low- $Q$ か ら high- $Q$ にかけて， $\Gamma / Q^{2}$ が一定 $\left(\Gamma \propto Q^{2}\right)$ とな る領域から， $\Gamma / Q^{2}$ が $Q$ に比例する $\left(\Gamma \propto Q^{3}\right)$ 領域 への転移が見られる。 これは， low- $Q$ では高分子 鎖が絡み合った網目鎖の拡散モード（協同拡散） が観察されるのに対して，網目のサイズに対応す る空間領域を境に，high- $Q$ では高分子鎖内部のセ グメント運動が観察されるためである[15].

セグメント運動が観察された $Q$ 領域における中 間散乱関数を Zimm モデルによって解析した.

Zimm モデルは，バネとビーズが連なったできた 連結鎖が溶媒中に存在する（ビーズ間に流体力学 的相互作用が働く）場合におけるセグメントダイ ナミクスを記述した理論モデルである[16]. CDを 含まない PEG 単独の溶液の場合, セグメントダイ ナミクスが観察される $Q$ 領域の中間散乱関数は, Zimm モデルによる予測とほぼ完全に一致した. 一方, Fig. 5 に示したように, ポリロタキサン溶 
液の中間散乱関数は Zimm モデルの理論曲線から 大きく逸脱した. Fig.5の点線は, SANS から算出 されたセグメント長 $b=5.1 \mathrm{~nm}$ および測定時の温 度 $\left(70^{\circ} \mathrm{C}\right)$ における溶媒の粘度 $\eta=1.34 \mathrm{cP}$ を用い た際の Zimm モデルによる理論曲線であり，ポリ ロタキサン溶液の中間散乱関数は理論曲線に比べ て緩和が遅いことが分かる。つまり，ポリロタキ サンの分子ダイナミクスは Zimm モデルによって 予測される分子運動よりも遅い。これは，ポリロ タキサンは CD を含んでいるため PEGのような通 常の高分子鎖に比べて分子鎖が太く，また CD の 包接によってより剛直な分子形態をとっているこ とが原因であると考えられる。

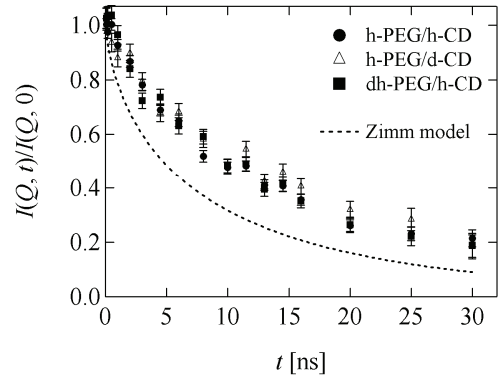

Fig.5 Intermediate scattering functions at $Q=0.08 \AA^{-1}$ for polyrotaxane solutions: h-PEG/h-CD $(\bullet)$; h-PEG/d-CD $(\Delta)$; and dh-PEG/h-CD(घ). The dashed line represents the prediction of Zimm model.

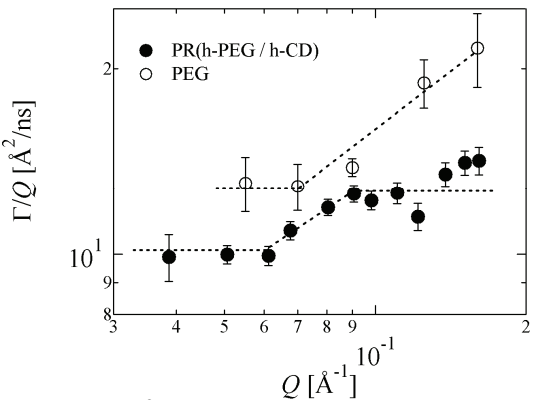

Fig.6 Plot of $\Gamma / Q^{2}$ as a function of $Q$ for PR and PEG in d-DMSO.

\section{4. 環動ゲルの力学物性}

環動ゲルの内部には, 軸高分子のセグメント運 動と環状分子のスライド運動という 2 種類の分子 運動が存在する.コントラスト変調 NSEの結果か ら，CDのスライド運動は PEG のセグメント運動 よりも十分遅いことが分かっている．従って，環 動ゲルの弾性率は Fig.7 に示した周波数依存性を 示すことが予想される。まず，軸高分子のセグメ ント運動のタイムスケールに対応する周波数でガ ラス状態（軸高分子のセグメント運動が凍結され た状態）からゴム状態（軸高分子のセグメントが 自由に運動している状態）への転移が起こる（ガ ラス-ゴム転移)。これは通常の高分子材料でも観 察される力学緩和である。ゴム状態を示す周波数 領域において，8 の字架橋点を含めて環状分子は 依然として軸高分子上でスライドすることができ
ないため，高分子は化学吕ルと同様，固定架橋点 によって架橋されていると見なすことができる. 従って，ゴム状態における復元力は高分子鎖の形 態エントロピー変化に由来する．次に，低周波領 域では，環状分子のスライド運動に対応した周波 数域において，ゴム状態から環状分子がスライド している状態（スライド状態）への力学緩和（ス ライディング転移）が起こると考えられる [17]. 実際，CD と PEGからなるポリロタキサンを架橋 した環動ゲルにおいて，ガラス転移とは異なる力 学緩和が観察されている $[18,19]$. スライド状態に おける環動吕ルの力学物性を議論する際には，軸 高分子の形態エントロピーに加えて，環状分子の 軸高分子上における一次元の配置エントロピーを 考慮する必要がある。

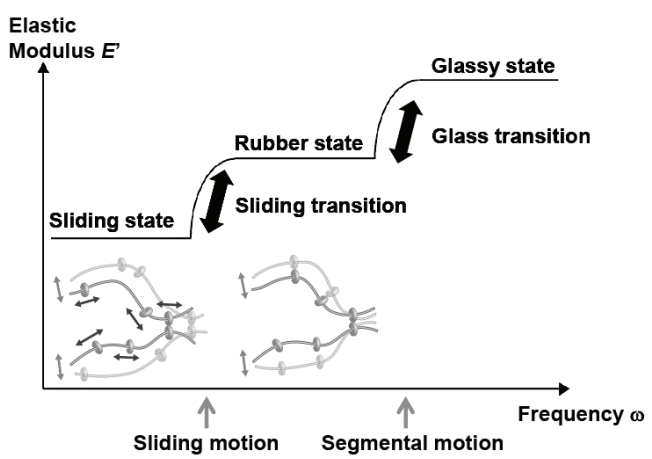

Fig.7 Dynamic modulus of slide-ring gels.

環動ゲルの 8 の字架橋点がスライドして，架橋 点間に存在する未架橋の環状分子が圧縮されると, 環状分子の配置エントロピーが減少して，架橋点 に復元力が生じる $[17,20]$.この時，架橋点間の未 架橋環状分子を気体分子，架橋点間の軸高分子鎖 をピストンと見なせば，環状分子によるエントロ ピー弾性は空気ばねとのアナロジーが成立する [17,20]. 実際に, 環動ゲルを一軸伸長すると, Fig.8 のように，延伸と垂直方向の環状分子は軸高分子 上で密に，延伸方向の環状分子は疎になり，架橋 点間の環状分子の空間分布に不均一性が生じて環 状分子のエントロピーが低下する。その結果，元 の均一な空間分布に戻ろうと復元力が働く.この 環状分子の配置エントロピーによる弾性は，通常 の紐のみからなる高分子材料には見られない新し いエントロピー弾性である。ポリロタキサンの状 態では互いに独立であった高分子の形態エントロ ピーと環状分子の配置エントロピーが，架橋した ことによって強く相関することになったことは注 目に值する.

ここで, 高分子の形態エントロピーと環状分子の 配置エントロピーの双方を考慮した理論モデルを 考える[21]. 環動ゲルにおける高分子の形態エン トロピーは Free Junction Model によって既に計算 されている[22]. Fig.8 に示したような，x，y，z 方向の 3 つの鎖から成る一つの単位格子に着目し, それぞれの鎖のセグメント数は初期状態では等し 

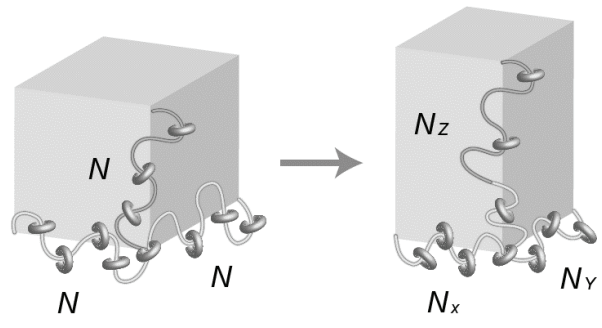

Fig. 8 Three chain model for polymer network with movable crosslinks and uncross-linked cyclic molecules on polymer chains.

$く N$ とする. $\mathrm{z}$ 方向に $\lambda$ 倍の変形が加わると $(\mathrm{x}$, $\mathrm{y}$ 方向は $\lambda^{-0.5}$ 倍に変形), 8 の字架橋点を通して $\mathrm{x}$, y 方向から $\mathrm{z}$ 方向にセグメントの移動が起こる. その結果， $\mathrm{x}, \mathrm{y}, \mathrm{z}$ 方向の各鎖のセグメント数が $N_{\mathrm{x}}, N_{\mathrm{y}}, N_{\mathrm{z}}$ に変化したとすると, 変形後の高分子 鎖の形態エントロピーは以下のようになる.

$S_{\text {Polymer }}=-\frac{3}{2} k_{\mathrm{B}} \sum_{i}\left[\frac{2 N}{\lambda N_{x}}+\frac{\lambda^{2} N}{N_{z}}+\ln N_{x} N_{y} N_{z}\right]$

この形態エントロピーを元に一軸伸長時の弾性率 を算出してみると, 弾性率はゼロとなる[21].つ まり，鎖が架橋点を完全に自由にすり抜けられる 場合には，高分子鎖に由来する復元力すなわちエ ントロピー弾性は生じないことになってしまう。.

そこで，環状分子の配置エントロピーを導入す ることにする．架橋点間の鎖上に存在する環状分 子の数を $n$ 個とし， 1 つの高分子セグメント上に 配置できる環状分子の数を 1 個とすると,

$$
S_{\mathrm{CD}}=k_{\mathrm{B}} \ln \prod_{i}^{x, y, z}{ }_{N_{i}} C_{n}
$$

となる [21]. ゲル変形後のセグメント数 $N_{\mathrm{x}}, N_{\mathrm{y}}$, $N_{\mathrm{z}}$ は，系全体のエントロピー $S=S_{\mathrm{Polmer}}+S_{\mathrm{CD}}$ が最大

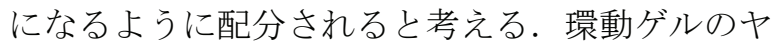
ング率 $E_{\mathrm{SR}}$ は，ゲルの変形によるエントロピー変 化から解析的に計算することができる：

$$
E_{\mathrm{SR}}=3 v k_{\mathrm{B}} T-9 v k_{\mathrm{B}} T \frac{1-f_{\mathrm{eff}}}{(2 N-3) f_{\mathrm{eff}}+3}
$$

$=E_{\text {Rubber }}-\Delta E$

ここで，Tはゲルの絶対温度, $v$ は網目鎖の数密度

（以下では架橋密度と呼ぶことにする）， $f_{\text {eff }}$ は架 橋点間における環状分子の充填率である。 上述の 通り, 架橋点間に環状分子がない場合は, 高分子 セグメントの移動は完全に自由に行われ，ゲルの 弾性率はゼロとなる。 しかし, 架橋点間に環状分 子がある場合, 高分子セグメントの移動によって 短くなった鎖上で環状分子の圧縮が起こるため, 高分子鎖の移動が抑制され，ゲルの弾性率は有限

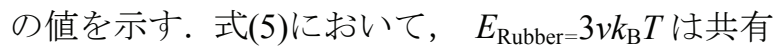
結合からなる通常の化学㐌ルの弾性率である. 従 って, 環動ゲルの弾性率 $E_{\mathrm{SR}}$ は, 架橋点が固定さ れた化学ゲルの弾性率 $E_{\text {Rubber }}$ に比べて, 架橋点の

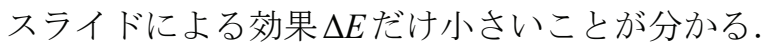

$\Delta E$ は架橋点における高分子鎖のスライドの効果 を定量化したものと見な寸ことができる.

環動ゲルの弾性率の特徵はその架橋密度依存性 に現れる。架橋密度の異なる環動ゲルを作製し， 一軸伸長試験を行った結果，環動ゲルの弹性率は 架橋密度に対して増加したのち，ある架橋密度を 境に減少に転じることが分かった（Fig. 9）[21]. 一般の化学ゲルの弾性率は架橋密度に比例して単 調に増加することが知られており，この特異な架 橋密度依存性は従来のゴム弾性理論とは一致しな い。しかし，環状分子のエントロピー弾性を考慮 した先述の理論モデルを用いると定性的な説明が 可能である。ここで重要になるのは，架橋点間の 充填率 $f_{\text {eff }}$ が架橋密度に依存するという点である. 架橋する前のポリロタキサンの環状分子充填率を $f$ とすると, 架橋密度が増加する（架橋点間のセ グメント数 $N$ が小さくなる）につれて架橋点間の 充填率 $f_{\mathrm{eff}}$ は $f$ から減少する (架橋点 1 つにつき環 状分子 2 個が使われる).

$$
f_{\text {eff }}=f-\frac{2}{3 N}
$$

式(5), (6)を用いて環動ゲルの弾性率の架橋密度に 対する変化を計算した結果を Fig.10 に示す. 環動 ゲルの弾性率 $E_{\mathrm{SR}}$ は架橋密度に対して増加した のち減少しており, この架橋密度依存性は実験結 果と一致する。架橋密度が高い場合，環状分子の ほとんどは架橋点に使われ，架橋点間に環状分子 はほぼ存在しない状態となる。この時，8の字架 橋点を通した高分子セグメントの移動が自由にな り，先述の Free Junction Model の結果より，ゲルの 弾性率は 0 に漸近して減少していくと考えられる.

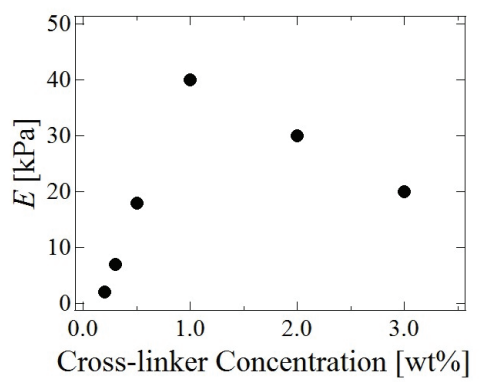

Fig.9 Plot of elastic modulus $E$ of SR gels as a function of cross-linker concentration.

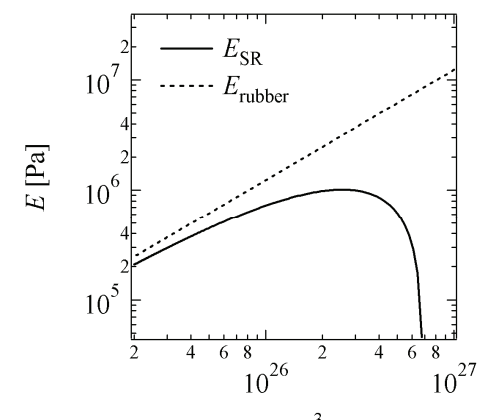

$v\left[\mathrm{~m}^{-3}\right]$

Fig.10 Plot of calculated elastic moduli for conventional chemical gels (dashed line) and slide-ring gels (solid line) as a function of strand density $v$. 


\section{5.まとめ}

本稿では, 線状高分子が複数の環状分子を貫い た分子複合体であるポリロタキサンの分子レベル における構造とダイナミクスをコントラスト変調 中性子散乱法によって観察した結果と，その実験 的知見を元にポリロタキサンの架橋体である環動 ゲルの力学物性を理解する分子論的描像について 紹介した. コントラスト変調中性子散乱法は複数 の構成要素からなる多成分系の精密な分子構造・ ダイナミクスの観察に非常に有用な手法である. コントラスト変調小角中性子散乱については既に 様々な系に応用されているが，コントラスト変調 中性子スピンエコー法については，実験の困難さ からか，まだそれほど多くの研究例はないようで ある．特に部分中閒散乱関数を精密に測定した例 はほとんどない，今後タンパク質を含む様々な超 分子複合体に適応し, 複合体内部の相対的な分子 ダイナミクスを観察したいと考えている。また， 本稿後半で述べた環動ゲルの分子論は, 溶媒を含 まない環動エラストマーにも適用可能であり, 環 動高分子材料の応用展開においても重要な示唆を 与えるものである. 環動高分子材料は現在, 携帯 電話の耐傷性塗料, 高性能誘電型アクチュエータ 一などへの応用が進められている. 従来の架橋高 分子材料にはない環動高分子材料の特長は, 架橋 されることで一定の堅さを有しながらも，架橋点 の可動性によって外場に対して柔軟に応答できる という点であろう。新規架橋高分子材料として環 動高分子材料がより幅広く実用化されることを期 待したい.

\section{6. 謝辞}

ポリロタキサン溶液に関するコントラスト変調 中性子散乱の研究は, 東京大学物性研究所の柴山 充弘先生, 日本原子力研究開発機構の遠藤仁博士, NIST 中性子研究センターの長尾道弘博士, ユーリ ッヒ中央研究所の Dieter Richter 先生と共同で行っ たものである。，小角中性子散乱の実験は日本原子 力研究開発機構の研究用原子炉 JRR-3 に設置され た SANS-Uにて行った．また中性子スピンエコー の測定は，ポリロタキサン溶液のコントラスト変 調実験をユーリッヒ中央研究所が所有する J-NSE, PEG 溶液の実験を東京大学物性研究所が所有する iNSE にて実施した. 環動ゲルの力学物性に関する 研究は, 東京大学伊藤研究室の板東晃徳氏, 手塚 正彦氏との共同研究である。共同研究者の皆様に この場を借りて感謝申し上げたい.

\section{参考文献}

[1] A. Ciferri, Supramolecular Polymers, Taylor \& Francis (2005).

[2] J. M. Lehn, Supramolecular Chemistry: Concepts and Perspectives. Weinheim: Wiley-VCH (1995).

[3] J. P, Sauvage and C. Dietrich-Buchecker, Molecular Catenanes, Rotaxanes, and Knots, Wiley-VCH (1999).

[4]. F. M. Raymo and J. F. Stoddart, Chem. Rev., 99 1643 (1999).
[5] A. Harada, A. Hashidzume and Y. Takashima, Adv. Polym. Sci., 201, 1 (2006).

[6] T. Takata, N. Kihara and Y.Furusho, Adv. Polym. Sci., 171, 1 (2004).

[7] J. Araki and K. Ito, Soft matter, 3, 1456 (2007).

[8] S. A. Nepogodiev and J. F. Stoddart, Chem. Rev. 98, 1959 (1998).

[9] T. Ooya and N. Yui, J. Control. Rel., 58, 251 (1999).

[10] Y. Okumura and K. Ito, Adv. Mater., 13, 485 (2001).

[11] K. Mayumi, H. Endo, N. Osaka, H. Yokoyama, M. Nagao, M. Shibayama and K. Ito, Macromolecules, 426327 (2009).

[12] H. Endo, K. Mayumi, N. Osaka, K. Ito and M. Shibayama, Polym. J., 43, 155 (2011).

[13] K. Mayumi, M. Nagao, H. Endo, N. Osaka, M. Shibayama and K. Ito, Physica B, 404, 2600 (2009).

[14] K. Mayumi and K. Ito, Polymer, 51, 959 (2010).

[15] D. Richter, M. Monkenbusch, A. Arbe and J. Colmenero, Adv. Polym. Sci., 174, 1 (2005).

[16] M. Doi and S. F. Edwards. The Theory of Polymer Dynamics, Oxford University Press (1986).

[17] K. Ito, Polym. J., 44, 38 (2011).

[18] G. Fleury, G. Schlatter, C. Brochon, C. Travelet, A. Lapp, P. Lindner and G. Hadziioannou, Macromolecules, 40, 535 (2007).

[19]. K. Kato and K. Ito, Soft Matter, 7, 8737 (2011).

[20] E. Sevick and D. Williams, Langmuir, 26, 5864(2010).

[21] K. Mayumi, M. Tezuka, A. Bando and K. Ito, Soft Matter, 8, 8179 (2012).

[22] K. Ito, Polym. J., 39, 489 (2007). 